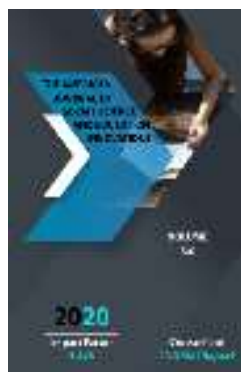

\title{
The Linguocultural Aspect Of Ethnographic Units In The Linguistic System ( The Example Of Wedding Ceremonies In Surkhandarya)
}

\author{
Nargis Shodievna Kurbonazarova \\ Teacher, Termez State University, Uzbekistan
}

Journal Website: http://usajournalshub.c om/index,php/tajssei

\section{ABSTRACT}

This article anatomizes the linguocultural aspects of some wedding ethnographies. The role of ethnographies in the language system and their semantics are also indicated. Along with a brief description of the field of linguoculturology of linguistics, the terms reality, stereotype, lacuna are also discussed. Famous linguists have commented on the views of scientists on this matter. Examples are given that wedding ceremonies are an expression of national realities and stereotypes. The analyzed ethnographies were selected from samples of wedding ceremonies of Surkhandarya oasis.

\section{KEYWORDS}

Linguoculturology, Eduard Sepir, reality, irreplaceable vocabulary, epic "Alpomish", stereotype, ritual, goat, king goat, groom goat, old man, sarpo allalatar.

\section{INTRODUCTION}

The linguistic system of each language has a system of units that reflects the spirituality, historical experience and culture of the nation using that language. The internal form of these elements reflects the original spirit of the national language as a phenomenon that unites the mentioned characters in their semantic scale. This semantics, saturated with expression, emotion, in turn, enriches the semantics of national folklore with a unique connotation. These units are ethnographies. 
In this article, we review the linguistic relevance and specific linguocultural circumstance of ethnography.

Language has a special value as the highest indicator of the behavior of each nation, reflecting traditions, values, the main features of national culture, a person's attitude to the world. Accordingly, in the study and research of language, which is the means of communication of people, it is important to take into account the process of communication, the situation, the purpose, behavior, psyche of the communicators. Since the process of using a language is a multifaceted, versatile activity, it reflects not only a person, but also the whole nation, people. Language is a mirror of culture, which reflects not only a real being that surrounds a person, his real living conditions, but also the social consciousness of the people, their mentality, national character, lifestyle, traditions, customs, morals, values and worldview [1]. In this, a person is the link between language and culture. Language and culture are so interconnected that there is no culture without language, there is no language without culture. That is, as Edward Sapir points out, culture is a set of practical skills and ideas that characterize our way of life, socially inherited [2], and language is a means of ensuring the periodicity of its existence. No matter how closely language and culture are related to each other, they also have their differences. While the goal of cultural scientists to study and explain the essence of concepts such as culture, ethics and aesthetics, the task of linguists is to determine the influence of culture on language and language on culture. The field of linguistic culture linguistics studies and analyzes these aspects of language. In addition, linguoculture is a complex (integrative) scientific science formed at the intersection of linguistics, culturology, ethnography, psycholinguistics, which studies the interdependence and interaction of language and culture, language and people, language and national mentality. Thus, the analysis of the basic principles, concepts of linguoculture, to get acquainted with the methods of interpreting the linguistic and cultural aspects of language units, the hidden appearance of language - allows us to learn a language related to human living condition.

Among the terms in the field of linguoculture, national reality occupies a special place. National realities are those that name objects, events and objects that are characteristic of the life, lifestyle, culture, socio-historical development of a particular nation, that are less familiar or alien to other peoples, words or phrases expressing national color that have no clear alternative in their language; one of the types of lexicon without alternative [3].

The manifestations of national reality in the national linguistic culture of the Uzbeks differ from the culture and nationality of other peoples of the world. The people of Uzbekistan are made up of people of different nationalities and ethnic groups. Although they have lived side by side in the same territory for many centuries and are related by kinship, they differ in their distinctive customs and rituals. In particular, the ancient Surkhandarya oasis of the republic differs from other regions by its ethnographic position, unique culture, customs and rituals of its population. The most vivid expression of culture - rituals are one of the national realities that reflect the history of the oasis, the culture of the people. Ritual is a work of life scene that has and will come with the demands and needs of human material and spiritual life, with natural action, decoration, and text. That is why there is no nation in the world that does not have its own rituals. Consequently, it serves as one of the important ethnographic features that make a particular 
nation different from other peoples. Because any ceremony occurs and lives in a relatively complete combination of the main features that reflect the level of economic, political and cultural development of a particular nation at a certain stage of historical development [4].

Surkhandarya wedding ceremonies, especially weddings, are a reflection of the national reality of the oasis. Each lexeme in it expresses nationality in itself. In a person unfamiliar with the history of the people, actions and words that have a different meaning actually take on a completely different meaning.

Weddings are celebrated differently in every culture and are expressed by different peoples through different customs, symbols and words. This creates complexity and inconvenience in explaining the idea that a language or culture owner wants to convey to another language or culture owner. The above points show that wedding ceremonies are lacunae. Lacuna (Latin lacuna "space, depth, hollow place"; French. Lacune "space, void") words and phrases that are characteristic of the domestic, cultural, social and historical life of a nation and are foreign to another nation, without a clear alternative in another language [5]. The ethnography of wedding ceremonies is a unique example of lacuna. Below we analyze some of such ethnographisms.

A capricorn is a child of a goat. In the language of many peoples of the world, it is the child of the goat that is translated as the kid and is not considered a lacuna when it comes to its meaning. But linguistically and culturally, this reality is in any case a wedding symbol in Surkhandarya, which has long been engaged in animal husbandry. It has existed among the traditions of our people since ancient times, sung in the epic "Alpomish" and still exists today:

The Uzbek tradition is as follows:

At noon the pure young men come,

Hakimbek was asked by the "groom's kid",

The people who asked just didn't stay,

He also gives them a sarka,

When the time is right, they will go away[6].

The "groom's kid" is given to the groom by the groom before the wedding is sent to the bride's house, or slaughtered. Therefore, it is just associated with the lexeme of the groom.

In the oasis, also through lexical means such as “kid", “shav kid", “king kid": 1. When a young man sends a wedding to the house of the future bride (Here the wedding is in the sense of dowry, gifts. According to ancient traditions, a live - sheep is also given. In this case, by mutual agreement of the parties, depending on the economic capacity of the groom, two or ten are given). the "disobedient kid" that goes in front of the wedding sheep (pronounced as "shav" with a phonetic change (Rich, Girl, Qumq.). "Shar" - "shav" - king, runaway, does not give a hand, plunder. The reason for its naming is that this kid with a scarf and money tied around his neck is given to the first person to catch it. So there will be a quarrel among many. A trembling kid escapes from the crowd. Finally someone catches the kid and makes his own. In many cases, the one who catches the kid with surkhanch tolerance and hospitality gives it to the owner of the wedding and the goat is slaughtered. 2. The meaning of "to quarrel" which is also felt in the above ceremony, is the meaning of the lexeme "kid" in Horse racing. That is, there will be a quarrel between the kids thrown into the Horse racing 
field. In the end, someone gets a chance and wins the grand prize.

In some areas of the oasis it is pronounced as "disobedient kid" - "king of kid" (music, farraginous, poem). 3. The child King also joins the wedding, which the groom sends to the bride's house. Only in this case, in addition to the meaning of the above "shar-shav" - playful, kachagan, stubborn, plunder, "king" - also means a leader. In addition, there is a ceremony "kid making a sarpo" (Uzun, Altynsay districts), in which the kid is used in a different sense. Here the bride's dowry is plundered (the kid is used in the sense of quarreling here. That is to say, it has the same meaning as the kidnapped goat in Horse racing). This ceremony is usually attended by women, girls and young children. A woman runs around the circle with a hug from the bride's dowry. People around are trying to get something out of the dowry. The bride's dowry is a symbol of blessing and happiness and has many hidden meanings. In this reality, the stereotype of the Surkhandarya people is shown, showing that the Surkhandarya people are a nation who believe in ancient myths. In the process of gathering the information, the informants also said that the ceremony of "kid making a sarpo" was an expression of how many young men the bride had robbed and taken away. (Khudoynazarova Chinnihol. Long district. Wedding and event organizer, retired). Whether the goal is set for the people of Surkhandarya, the spirit of achieving it, no matter how many difficulties, will be a priority. Sung in epics, this character inherited from Alpomish is a stereotype for the Surkhandarya people.

An old bone is a dish that is put in front of the groom on the wedding day. In Termez and Sherabad districts of Surkhandarya there is a form of love bone. This reality is also a gap in the speech of other speakers, and has a completely different meaning for those who do not have a full understanding of Uzbek culture and traditions. In this case, the groom is placed on the groom's table when he goes to his house with his friends and relatives to pick up the bride. It is eaten first by the groom and then by his friends, who in turn bite him. The old bone is actually the bone of the young cattle, not the old cattle. This bone is the front leg of the cattle, and the marrow (bone fat) starts from that leg, and first that leg is filled with fat. The name of the place refers to the fact that the groom lived a long life and was full of energy even in old age. When the bone is called the marrow, it refers to the joint at the top of the bone. It means to be in love, to be in love with each other.. It is the lover in the combination of falling in love that is associated with the name of this bone (this custom exists in almost all regions of the oasis). Here the people of Surkhandarya, who express this reality, are engaged in animal husbandry, love and consumption of meat products, putting meat on the table of distinguished and esteemed guests is a stereotype unique to Surkhandarya and is a linguocultural unit that reflects the culture.

It is clear that in order to have an idea of a nation, it is necessary to pay attention to its national reality. It is difficult to express an opinion about a nation without understanding the meanings of the "inner" language that represents culture. It is safe to say that originality is distinguished by the ability of language to represent culture. This is a clear example of the commonality of language and culture.

\section{REFERENCES}




\begin{tabular}{|c|c|}
\hline 1. & Usmonova $\quad$ Sh. \\
\hline & $\begin{array}{ll}\text { Linguoculturology. } & \text { Textbook. } \\
\text { Toshkent, p.7 } & \end{array}$ \\
\hline 2. & $\begin{array}{l}\text { Sapir E. (1993). Selected works on } \\
\text { linguistics and cultural studies. } \\
\text { Moscow, } 185 \mathrm{p.}\end{array}$ \\
\hline 3. & $\begin{array}{l}\text { Khudoyberganova D. (2015). A concise } \\
\text { glossary of linguoculturological terms. } \\
\text { Tashkent: "Turan zamin ziyo", p. } 32\end{array}$ \\
\hline 4. & $\begin{array}{l}\text { Sarimsoqov B. (1986). Uzbek } \\
\text { ceremonial folklore. Tashkent, } \\
\text { Uzbekistan USSR "Science", p. } 9\end{array}$ \\
\hline 5. & $\begin{array}{llr}\text { Usmonova } & \text { Sh. } & \text { (2019). } \\
\text { Linguoculturology. } & \text { Textbook. } \\
\text { Tashkent, p.129 } & & \end{array}$ \\
\hline
\end{tabular}

6. Alpomish: Uzbek folk heroic epic. (1998). Narrator: Fozil Yuldosh oglu, writer: M. Zarifov. Tashkent : "Sharq", p.167

7. Kurbanazarova N. Sh. (2020). Linguistic Study of some Uzbek Ethnographisms Expressing Wedding Ceremonies. International Journal of Psychosocial Rehabilitation, No.5, Pp. 3735-3740

8. Kurbonazarova N. (2019). A REVIEW OF SOME WEDDING CUSTOMS IN THE SURKHANDARYA AREA. Theoretical \& Applied Science, Pp. 405-410.

9. Qurbonazarova N. (2019). Etnografizmlar xalq madaniyatini ifodalovchi muhim lingvistik birlik. Ima sarchashmalari. 8/1. P. 38

10. Qurbonazarova N. (2019). Hakim Termiziy va Fariduddin Attor. No.2, P. 39

11. Shomansurkizi, R. Z. (2020). Jargan in uzbek language and its study. ACADEMICIA: An International Multidisciplinary Research Journal, 10(6), 1149-1153.

12. Рахимова 3.Ш. (2019). Жаргонлар чегараланган лексик бирлик сифатида. Научный вестник 